УДК 811.163.41'367.625

811.163.41'373.611

https://doi.org/10.18485/kij.2018.65.1_2.3

\author{
ДУШАНКА С. ВУЈОВИЋ \\ Универзитет у Новом Саду \\ Филозофски факултет
}

Оригинални научни рад

Примљен: 12. 03. 2018.

Прихваћен: 26. 05. 2018.

\title{
ПРЕФИКСАЦИЈА ГЛАГОЛА У СИСТЕМУ ТВОРБЕ РЕЧИ**
}

\begin{abstract}
Глагол је веома важна категорија у језику, а глаголска префиксација изазива пажњу jep је њен статус у науци о творби речи могуће интерпретирати на различите начине. У раду се приказују могућности интерпретације префиксираних глагола у светлу творбе речи, у граматичкој литератури и у речницима стандардног српског језика. На примеру општег дела речничке дефиниције седам типичних глаголских префикса до-, од-, из-, $y$-, нa-, пре- и раз- приказан је различит статус глаголских префикса и глаголске префиксације у два стандардна речника српскога језика. Општи закључак рада је да префикси и предлози нису исти односно, да префикси нису предлози спојени са основом речи, као што се сматрало у нашим традиционалним граматикама. Последица тог закључка је схватање префиксације глагола, па и префиксације уопште као посебног, аутономног творбеног поступка.
\end{abstract}

Кључне речи: творба речи, глаголска префиксација, слагање речи, префикс.

У оквирима творбе речи, префиксација уопште, а нарочито глаголска префиксација, привлачи пажњу јер су у нашим граматичким приручницима уочљиви различити приступи тој теми. Савремени школски уџбеници углавном се приклањају традиционалном приступу под утицајем старијих теорија творбе речи и класификацији по којој је префиксација уопште, а самим тим и префиксација глагола, сматрана творбеним поступком слагања речи.

Зашто је творба речи важна тема? Креативна енергија језика је неисцрпна, а у један од извора његове креативности, поред осталих, спада и творба речи. Она је, поред, наравно, полисемије, један од најважнијих поступака у стварању нових речи и у богаћењу лексикона, како једног језика, тако и сваког његовог

*dusanka.vujovic@ff.uns.ac.rs

** Рад је настао у оквиру пројеката Стандардни српски језик: синтаксичка, семантичка и прагматичка истраживања (178004), који финансира Министарство за просвету, науку и технолошки развој Републике Србије. 
говорника понаособ. Творба речи је снага и погон језичке креативности. Она је жив процес са којим се суочавамо свакодневно и свако од нас је, у једном тренутку бар, током свог живота, био сведок настанка неке нове речи путем творбе и на тај начин учествовао у језичкој чаролији стварања нових речи. Упознавање са начинима творбе речи, поготово за децу основношколског узраста, веома је важно јер схватајући творбене поступке и принципе, у стању су и сами да креирају нешто ново, а прихватљиво језичком изразу и језичкој норми, као и да лако схвате и разумеју нешто што им је на први поглед непознато и са чиме се раније нису срели.

Друго питање је - зашто су глаголи важна тема. У систему језика глаголу припада посебно место. Због своје широке семантичке базе, лексичке слојевитости, обличке разноврсности и изузетне сликовитости и изражајности, он, уз именицу, представља основну врсту речи. Глагол је веома сложена и широка граматичка категорија која је веома важна за језик. Свака комуникација почива на глаголу јер је он језичко средство које омогућава да се ванјезичка реалност искаже у пуној својој дијалектици. „Глагол је као лексичко-граматичка врста речи један од најважнијих структурних елемената граматички обликованог исказа, а тиме и језика и његове комуникативне функције” (Тошовић 1995: 7). Њиме се формира динамика исказа.

Треће питање је - зашто је префиксација важна тема. Заокупљеност граматичара суфиксацијом, као доминантним видом творбе речи, у домаћој лингвистици довела је до тога да се о префиксацији уопште врло мало писало‥ У новије време и префиксација све више заокупља пажњу лингвиста и све су бројнији научни радови који се баве том темом.

Други разлог лежи у томе што се префиксација може схватити на различите начине. Неки граматичари је схватају као слагање речи, други је схватају као посебан, аутономан творбени поступак, а неки је чак сврставају у извођење. Навешћемо неке од значајнијих.

У старијим радовима о творби речи префикс се углавном не дефинише. Томо Маретић у својој граматици из 1899. и не спомиње појам 'префикс' већ сматра префиксалне творенице сложеницама с предлозима тако да све префиксе, укључујући и оне који се не јављају самостално, назива предлозима (Маретић 1899).

Александар Белић, један од наших најзначајнијих и најутицајнијих лингвиста, сматрао је да су префикси настали од предлога, због чега је префиксе изједначавао са предлозима (Белић 1949). Последица тога је традиционално схватање префиксације као слагања речи и сврставање речи са префиксима међу сложенице.

И Белићев следбеник, Михајло Стевановић, 1964. г. у књизи Савремени српскохрватски језик, у поглављу „Сложенице с префиксима” дефинише префикс

${ }^{1}$ У књизи Ивана Клајна (2002: 173-182) налази се информативан и детаљан преглед ставова домаћих граматичара о префиксима и префиксацији као начину творбе речи. 
као „предлог, који је тек срастањем с другим делом сложенице постао префиксом" (Стевановић: 1964: 425).

У књизи Приручна граматика хрватског књижевног језика из 1979. г. Еугенија Барић са сарадницима префиксалну творбу не сматра више слагањем, већ је издваја као посебан творбени поступак у коме се творбено значење речи изражава помоћу префикса или предметка (Барић 1979: 230).

Стјепан Бабић у својој књизи Творба ријечи у хрватском језику из 1986. г. префиксалну творбу сматра слагањем, али схватајући специфичности префиксалне творбе, префиксалне творенице убраја у посебну врсту сложеница (Бабић 1986: 33).

У новије време, схватање префиксације као посебног творбеног поступка налазимо и код Ивана Клајна у његовој књизи Творба речи у савременом српском језику (2002) у којој он износи следеће: „Закључак да префикси нису предлози, дакле нису речи, него су афикси, нужно подразумева и да се префиксација не може сматрати врстом слагања, као у нашим досадашњим граматикама.” (Клајн 2002: 178). Он предлаже да се префиксација као и суфиксација сматра посебним начином творбе речи.

Милица Радовић Тешић у својој књизи Именице с префиксима у српском језику (2002) износи мишљење да је префиксација посебна врста творбе речи са извесним елементима слагања, које се очитује у самом процесу спајања префикса са творбеном основом. Из самог назива књиге Именице са префиксима види се њена опредељеност да префиксацију сматра посебним творбеним начином.

Божо Ћорић у књизи Творба именица у српском језику префиксацију, заједно са суфиксацијом, сматра извођењем јер оно обухвата афиксацију уопште па према томе, како суфиксацију тако и префиксацију (2008: 16).

Шта о префиксима можемо да пронађемо у речницима? Статус префикса и префиксације као творбеног поступка, осим у граматикама види се и у речницима, како терминолошким, тако и стандардног језика.

У Речнику српскохрватског књижевног језика Матице српске (РМС: 1976) префикс се изједначава са предметком тј. њиме се упућује на предметак, а предметак је дефинисан на следећи начин ,у сложеним речима онај део који је испред корена (обично предлог)”. И овом дефиницијом се префикс, углавном, изједначава са предлогом, што је било сасвим уобичајено у време када је речник настајао. У Речнику српског језика Матице српске из 2011. г. (РСЈ: 2011) види се помак у схватању префикса који се више не дефинише преко предлога већ као „творбена морфема која се додаје на почетак речи или основе речи и тако твори нову реч”, што је, чини се, последица савременијих схватања о префиксима и префиксацији. Предметак се у овом речнику као синоним за префикс више углавном и не користи.

Префиксација је у оба речника слично дефинисана, у РМС као „начин творбе речи помоћу префикса”, а у РСЈ нешто шире, као „творба речи уз помоћ префикса, префиксална творба речи". 
Међутим, какво је схватање префикса и глаголске префиксације, боље од саме дефиниције тих појмова показују сами речнички чланци у којима су дефинисани различити префикси. Узели смо за пример седам типичних глаголских префикса до-, од-, из-, y-, на-, пре- и раз- и анализирали њихов genus proximum тј. општи део у њиховој речничкој дефиницији, у речницима стандардног српског језика РМС и РСЈ. Приметили смо да се као општи део појављује десетак сличних, али не потпуно истих конструкција. То су следеће конструкције:

- префикс у глаголским сложеницама,

- префикс у сложеним глаголима,

- префикс у сложеним глаголима и њиховим изведеницама,

- префикс сложених глагола (и њихових изведеница),

- префикс у сложеницама с глаголским речима,

- предметак при творби глагола,

- префикс у глаголима,

- префикс у глаголима (и изведеницама од њих),

- предметак или префикс у творби глагола,

- префикс у творби глагола.

Све ове конструкције могле би бити сведене на два типа: 1) префикс у сложеним глаголима и 2) префикс у творби глагола. Први тип нам говори о томе да аутор чланка сматра префиксиране глаголе сложеним твореницама, тј. сложеницама, а други тип нам не даје никакву информацију о томе да ли префиксалну твореницу сматра сложеницом или не, већ само идентификује глаголски префикс као творбени елеменат у творби глагола.

Приликом анализе општих делова дефиниција различитих префикса у два стандардна речника српског језика, очекивано је да оне буду уједначене, односно да се у речнику налази или један или други тип дефиниције, што је, углавном, и потврђено у РМС. Иако се, формално, општи део дефиниција анализираних префикса у њему не подудара, садржајно су оне углавном подударне и припадају првом типу. Незнатно одскачу једино дефиниције префикса из- и пре- у којима се не наводи експлицитно да је префикс творбени елеменат у глаголским сложеницама, већ у творби глагола. У РСЈ је ситуација мало другачија јер се у четири дефиниције каже да је префикс творбени елеменат у творби глагола, а у три да је творбени елеменат у творби сложених глагола. Неусаглашеност дефиниција ових неколико префикса наводи на помисао да статус префикса и префиксалне творбе у овом речнику није јасно диференциран. Међутим, на основу овако малог броја огледних примера, ипак, не смемо изводити генерални закључак за који би ваљало урадити и једно широко истраживање у коме бисмо упоредили начин представљања већине префиксалних твореница у оба речника. Такво истраживање би нам дало јаснију слику о статусу префикса и префиксације у нашим речницима стандардног језика. 
Табела 1. Genus proximum за префиксе од-, до-, из-, y-, на-, пре- и раз-

\begin{tabular}{|l|l|l|}
\hline префикс & \multicolumn{1}{|c|}{ РМС } & \multicolumn{1}{|c|}{ РС } \\
\hline до- & префикс у глаголским сложеницама & префикс у глаголима \\
\hline од- & префикс у сложеним глаголима & $\begin{array}{l}\text { префикс у сложеницама с } \\
\text { глаголским речима }\end{array}$ \\
\hline из- & предметак при творби глагола & префикс у творби глагола \\
\hline у- & $\begin{array}{l}\text { префикс у сложеним глаголима и } \\
\text { њиховим изведеницама }\end{array}$ & $\begin{array}{l}\text { префикс у сложеним глаго- } \\
\text { цама и њиховим изведени- }\end{array}$ \\
\hline на- & $\begin{array}{l}\text { префикс у сложеним глаголима } \\
\text { пре- }\end{array}$ & $\begin{array}{l}\text { префикс у глаголима (и из- } \\
\text { веденицама од њих) }\end{array}$ \\
\hline глагола \\
раз-
\end{tabular}

У Енциклопедијском рјечнику лингвистичких назива Рикарда Симеона који смо узели као представника терминолошких речника, наводи се више дефиниција префикса различитих аутора. Оно што је заједничко већини дефиниција јесте да се префикс дефинише као врста афикса који се ставља испред корена или основе речи (Симеон 1969).

Шта о префиксалној творби речи проналазимо у школским граматикама? У школским граматикама творба речи се представља на традиционалан начин и у њеним оквирима издвајају се два основна творбена поступка, слагање или композиција и извођење или деривација, а осим њих, наводе се још и комбинована творба и творба претварањем (конверзија). Префиксација се сврстава у творбени поступак слагања. Наравно, ово је сасвим разумљиво јер школско градиво прати задати план и програм. Стога је већа пажња поклоњена суфиксалном начину творбе као доминантном у српском језику, а када се говори о префиксацији узимају се најчешће примери именичке префиксације. Слагање (композиција) се обично дефинише као творба речи помоћу срастања двеју или више посебних речи, односно њихових творбених основа у једну реч. Као посебно продуктивни тип сложеница наводе се и оне које су добијене од префикса и речи главних врста (именица, придева, глагола): написати (од на- + писати), договорити се (од до- + говорити), довратак (од до- + врата + ак), безбрижан (без- + брижан), подјезични (од под- + језични). 
Префикс се обично дефинише као несамостална морфема која долази испред корена речи, творбене основе или целе речи и модификује њено значење. Ако смо већ дефинисали слагање као поступак спајања две посебне речи, онда може да збуни сврставање префиксације у слагање јер префикс није посебна реч. Међутим, ако узмемо примере твореница у којима се појављују облици префикса исти са предлогом, онда немамо проблема јер они и јесу настали спајањем две посебне речи. На пример, потпалубље (под палубом), бесквасни (без квасияа). Али како ћемо објаснити творенице грађене од префикса про-, као што су нпр. протрчати, проговорити, промислити, или од префикса раз- у растрчати се, распремити, рашчешљати се, разуверити и сл.? Из дефиниције сложених речи испада да су префикси про- и раз- посебне речи, што никако не може бити.

Префикс и предлог нису исти, односно, префикси нису предлози спојени са основом речи. Префикси су, гледајући дијахронијски, настали од предлога и задржали њихов облик, али се семантичка и функционална веза међу њима изгубила и префикси су постали посебни несамостални творбени елементи посве различити од предлога. То потврђују следеће чињенице: прво, број префикса који се никада не појављују самостално већи је него што се то раније мислило и него што то представљају граматике (Клајн 2002: 176). Нпр. префикси нај-, пра-, пре-, про-, раз-, су-, нуз-, који се налазе у речима највиши, праунук, препешачиmи, пролетети, разићи се, сународник не јављају се самостално као предлози, што значи да нису предлози. Друго, има доста префикса који су формално исти са предлогом али се од њега у значењу потпуно разликују. Нпр. префикс по- у полетети или у помајка не може да се изједначи нити са једним значењем (има их петнаестак у РМС) предлога по. Или префикс на- у натрчати се, најести се, наглув ... такође нема никакве семантичке везе са предлогом на. Ову разлику у значењу региструје и РМС, где нпр. предлог на има близу педесет значења, а на- као префикс има тринаест значења сасвим различитих од значења предлога на. Тим је чуднија дефиниција префикса у РМС у којој се упућује на предметак, а предметак је, као што смо већ коментарисали ,у сложеним речима онај део који је испред корена (обично предлог)". Значи и у дефиницији префикса у РМС изједначени су префикс и предлог, а ипак се у, оквиру самих одредница, као што је нпр. одредница на-, бележи разлика у значењу и наводе се посебна значења за предлог а посебна значења за префикс. То је један од могућих аргумената за потпуно одвајање префикса од предлога и утврђивање префикса као посебне несамосталне творбене јединице.

О несамосталности префикса говори и чињеница да их у лингвистичким речницима ${ }^{2}$ дефинишу као афиксе, а афикси су по дефиницији несамосталне творбене јединице, односно како се каже у Симеоновом речнику, везане морфеме (Симеон 1969). Значи префикси су несамосталне творбене јединице односно везане морфеме, што искључује могућност да су префикси, заправо, предлози.

${ }^{2}$ Симеон 1969, Кристал 1988, Јарцева 1990. 
Међутим, неки префикси имају исти облик као предлози нпр. код деноминалних придева префиксално-суфиксалне творбе и префиксалних именица. У том случају „се твореница може мотивисати синтагмом предлог + именица: поткровље = оно што је под кровом, противотров = оно што делује против отрова, безболан = који је без бола, ванземаљски = који је ван Земље итд." (Клајн 2002: 177).

Префикси се најчешће користе у творби глаголских префиксала. Код њих, чак ни у оним случајевима у којима постоје идентични облици префикса и предлога, не можемо говорити о настанку префикса од предлога, опет из више разлога.

Предлошко глаголске конструкције се уопште на јављају у нашем језику. Због тога глаголи истрчати, улетети, преписати нису могле настати од предлошко-глаголске синтагме из трчати, у летети, пре писати.

Осим тога, врло честа рекцијска допуна неких глагола, јесте предлошко-падежна конструкција у којој је предлог по свом облику и по свом значењу исти као префикс. „Није реткост да се префикс префигираног глагола кретања формално и семантички подудара са предлогом, нпр. изаћu из, ућu y, отићи од и сл.” (Вујовић 2012: 283) То би могло да значи да префикс није предлог јер би било тешко могуће да се предлог са истим значењем дуплира и појави и испред и иза глагола.

И код глагола које префикс само перфективизује, нпр. јести - појести, као нпр. и код оних у које префикс уноси дистрибутивно или ингресивно значење, као што су поудавати или закорачати, постоји само формална подударност између префикса и предлога, али не и семантичка јер значење које уноси префикс у твореницу није исто са значењем предлога који је његов формални коресподент.

На основу свега реченог, јасно је да префиксе и префиксацију није једноставно дефинисати и да постоје разлози због ког се префиксација сматра слагањем, али и они због којих то није увек могуће. Иако се префиксација, традиционално, сматра слагањем, због чега је тако најчешће и представљена у граматикама и у школским уџбеницима, сматрамо да би префиксацију уопште, а поготово префиксацију глагола, због своје специфичности, требало ипак сврстати у један аутономни вид творбе, јер, као што смо видели, префикси су афиксалне морфеме које могу да се подударају са предлогом формално и семантички, али често то и није случај, што је један од најважнијих разлога да префиксацију не сматрамо слагањем.

Увођењем префиксације, као посебног творбеног начина, међу основне творбене поступке, прави се несклад у симетрији по којој смо имали два основна начина творбе, извођење и слагање, али није све у језику у некој дивној хармонији и складу и чини се да због тога и јесте толико узбудљиво проучавати језик и бавити се питањима његове семантике, структуре и организације. 


\section{ЛИТЕРАТУРА}

Бабић 1986: S. Babić, Tvorba riječi u hrvatskom književnom jeziku : nacrt za gramatiku, Zagreb: Globus.

Барић 1979: E. Barić i dr., Priručna gramatika hrvatskoga književnog jezika, Zagreb: Školska knjiga.

Белић 1949: А. Белић, Савремени српскохрватски књижевни језик. II. Наука о грађењу речи, Београд: Научна књига.

Вујовић 2012: Д. Вујовић, Деривација и рекција глагола ићи, Међународни тематски зборник: Валентност речи и израза: морфосинтаксички, семантички и прагматички аспекти, Нови Сад: Филозофски факултет.

Јарцева 1990: В. Н. Ярцева, Лингвистический энциклопедический словарь, гл. ред. В. Н. Ярцева, Москва: Советская эниииклопедия.

Клајн 2002: И. Клајн, Творба речи у савременом српском језику. Први део. Слагање и префиксаиија, Београд - Нови Сад: Завод за уџбенике и наставна средства и Институт за српски језик САНУ - Матица српска.

Кристал 1988: K. Dejvid, Enciklopedijski rečnik moderne lingvistike, Beograd: Nolit.

Маретић 1899: T. Maretić, Gramatika i stilistika hrvatskoga ili srpskoga književnog jezika, Zagreb: Kugli i Deutsch.

PMC 1976: Речник српскохрватског књижевног језика књ. 1-3, Нови Сад - Загреб: Матица српска - Матица хрватска, 1967-1969, књ. 4-6, Нови Сад: Матица српска, 1971-1976.

PCJ 2011: Речник српскога језика, Нови Сад: Матица српска.

Симеон 1969: R. Simeon, Enciklopedijski rječnik lingvističkih naziva. I-II, Zagreb: Matica hrvatska.

Тешић 2002: М. Радовић Тешић, Именице с префиксима у српском језику, Београд: Институт за српски језик САНУ.

Тошовић 1995: B. Tošović, Stilistika glagola, Wuppertal: Lindenblatt. 
Dušanka S. Vujović

VERBAL PREFIXATION IN THE WORD FORMATION SYSTEM

Summary

Prefixation cannot be easily considered as one of the two basic word-formation methods, derivation or compounding. There are arguments for and against considering it to be either one of them. Although prefixation is traditionally viewed as a form of compounding, which is why it is commonly presented in grammars and textbooks as one, we believe that prefixation in general, and prefixation of verbs in particular (due to its specificity) should be considered an autonomous type of word-formation. The reason for this is that prefixes are affixal morphemes, often formally and semantically corresponding to prepositions, but not always - which is one of the most important reasons why prefixation can be considered a special type of word-formation.

Key words: word formation, verbal prefixation, compounding, prefix. 